\title{
Bay Leaf Oil
}

National Cancer Institute

\section{Source}

National Cancer Institute. Bay Leaf Oil. NCI Thesaurus. Code C107271.

The essential oil of Laurus nobilis. Bay leaf oil can be used to ease muscular aches and pain. 